\title{
Kecemasan masa depan dan sikap mahasiswa terhadap jurusan akademik
}

p-ISSN 2746-8976; e-ISSN 2685-8428

ejournal.umm.ac.id/index.php/cognicia 2021, Vol 9(1):11-16

DOI:10.22219/cognicia.v9i1.15292

(C)The Author(s) 2021

(c)(1) 4.0 International license

\author{
Firanda Putri Maharani ${ }^{1}$, Diah Karmiyati ${ }^{1}$, dan Dian Caesaria Widyasari ${ }^{1}$
}

\begin{abstract}
It is often found that students feel they are in the wrong major which leads to feeling confused about choosing their future career. As a result, students think they cannot choose a career that suits their major and end up feeling anxious about their future. This study aims to determine the relationship between future anxiety and student attitudes towards academic majors. This correlational quantitative research involved 150 samples based on purposive sampling with characteristics as active students in university located in East Java, female or male aged 18-25 years. The instruments used were Future Anxiety Scale for future anxiety variables and Attitude toward Specialization Scale for attitude toward academic majors. Based on the Pearson correlation product moment test showed that there was a positive relationship between future anxiety and student attitudes towards academic majors $(r=0,326, p<0.001)$ with contribution of $10.6 \%$. The higher the level of future anxiety of students, the more positive student's attitude towards their academic majors. Implications that refer to the results of this research for students who are feeling anxious about the future so they can respond to their academic majors positively.
\end{abstract}

\section{Keywords}

Future anxiety, attitude, students.

\section{Pendahuluan}

Pada tahun 2020, data dari Kepala Badan Pusat Statistik (BPS) Kota Malang menunjukkan jumlah pengangguran tertinggi di Provinsi Jawa Timur, yaitu mencapai 27.664 orang atau 6,04\%. Angka tersebut didominasi oleh calon tenaga kerja lulusan pendidikan menengah ke atas dan perguruan tinggi (Ramadhan, 2020). Menurut Indonesia Career Center Network (ICCN) salah satu penyebab pengangguran karena sebanyak $87 \%$ mahasiswa Indonesia mengakui bahwa jurusan yang diambil tidak sesuai dengan minat pada survei yang dilakukan tahun 2017 (Awaliyah \& Murdaningsih, 2019). Awaliyah \& Murdaningsih (2019) lebih lanjut menyampaikan hal ini berkontribusi terhadap 71,7\% pekerja yang memiliki profesi tidak sesuai dengan latar belakang pendidikan yang ia tempuh atau dikenal dengan istilah mismatch. Memilih jurusan kuliah bukanlah hal yang mudah bagi siswa SMA, mengingat Perguruan Tinggi di Indonesia menyediakan banyak sekali pilihan jurusan. Biasanya banyak lulusan SMA memilih jurusan berdasarkan trend dan prospek kerja yang menjanjikan sehingga mengesampingkan kemampuan dan kurang selaras dengan minat atau hobi mereka (Setiawan, 2013).

Salah satu alasan terjadinya mismatch yang dikemukakan oleh responden sebanyak $50,55 \%$ bersumber dari faktor eksternal yang membuat mahasiswa merasa keliru memilih jurusan, seperti dorongan orang tua, ikut teman atau karena anggapan lulusan jurusan tertentu lebih mudah memperoleh pekerjaan. Kekeliruan ini kemungkinan berdasarkan dari ketidaktahuan dan ketidakmengertian akan minat dan bakat diri sendiri sehingga memilih jurusan hanya berdasarkan rekomendasi teman atau orang tua.
Fenomena ini kerap terjadi hingga memberikan dampak yang mengarah ke hal negatif. Artikel pada website resmi Institut Teknologi Sumatera menjelaskan bahwa mahasiswa dapat mengalami masalah psikologis apabila merasa salah memilih jurusan. Masalah psikologis tersebut, seperti daya tahan terhadap tekanan, konsentrasi dan menurunnya daya juang. Selain itu, membuat mahasiswa kurang percaya diri karena kurang mampu menguasai materi perkuliahan sehingga mendapatkan hasil yang kurang memuaskan. Hermawan (2012) juga mengatakan bahwa salah memilih jurusan berdampak pada nilai kuliah, merasa tertekan, menyebabkan drop out dari kuliah, tidak bergairah kuliah bahkan bingung mencari kerja yang sesuai dengan jurusan. Dampak negatif dalam sikap terhadap pemilihan jurusan ini banyak mengarah pada menurunkan performa akademik hingga kehilangan motivasi belajar.

Sikap bahwa mahasiswa beranggapan salah memilih jurusan dapat merugikan mahasiswa karena banyak diantara mereka mengaku ekspektasi saat memilih jurusan berbeda dengan realita saat sudah menjalani perkuliahan dan $40 \%$ mahasiswa memutuskan drop out di tahun pertama karena menganggap salah mengambil jurusan dan merasa proses belajar tidak sesuai dengan harapan. Williams (1984) menegaskan bahwa pilihan jurusan adalah tahapan yang penting bagi mahasiswa karena memilih jurusan yang

${ }^{1}$ Universitas Muhammadiyah Malang, Indonesia

\section{Korespondensi:}

Firanda Putri Maharani, Fakultas Psikologi Universitas Muhammadiyah Malang

Email: firandamaharani@gmail.com 
tepat dapat menentukan hidupnya termasuk kemudahan memperoleh pekerjaan di masa depan.

Selain itu, mahasiswa merasa salah jurusan juga karena adanya pandangan negatif terhadap jurusan yang diambil dari masyarakat umum dan pemberi kerja. Banyak dijumpai bahwa mahasiswa mengaku cemas dan merasa salah jurusan akibat stereotip yang melekat terhadap jurusan yang ia ambil (Kompas, 2015). Hal tersebut disebabkan banyak masyarakat umum yang menganggap beberapa jurusan tergolong bagus dan jurusan lain tidak bagus. Seperti artikel yang dikutip dari Vice mengenai "Stereotipe Mahasiswa Eksak Konservatif Sementara Anak Fakultas Sosial Lebih Liberal" menjelaskan bahwa mahasiswa dengan jurusan eksak dipandang lebih borjuis-liberal, borjuis-konservatif, konservatif-proletar, dan liberal-proletar sedangkan mahasiswa dengan jurusan sosial masuk kategori liberal dan proletar. Padahal pandangan tersebut belum tentu menggambarkan realita seseorang hanya berdasarkan jurusan yang diambil.

Pada dasarnya sikap mengarah pada sesuatu yang kita suka atau tidak terhadap sesuatu. Selain itu, sikap juga sering dihubungkan dengan suatu persepsi dan tingkah laku yang diberikan dari suatu perangsang. Situasi seperti itu dapat mempengaruhi emosi atau perasaan individu yang kemudian memunculkan perilaku tertentu sebagai respon atau reaksi dari stimulus, baik secara positif maupun negatif. Sikap memiliki komponen kognitif yang meliputi kepercayaan, pemikiran atau persepsi individu dan informasi tentang beberapa subjek atau situasi, juga memiliki komponen emosional yang mengacu pada perasaan dan emosi individu tentang subjek atau situasi tertentu, sementara komponen perilaku terkait dengan kesiapan individu untuk melakukan tindakan dan respons tertentu konsisten dengan sikap mereka.

Rajecki (1982) melihat bahwa ketiga komponen itu konsisten untuk individu memunculkan sikap tertentu. Mereka harus mulai dengan memahami situasi yang dihadapi berdasarkan informasi dan pengalaman baru yang mengarah pada sebuah perubahan sentimental, dan mereka tampaknya menerima atau menolak situasi hingga membentuk komponen perilaku. Mahasiswa yang berfikir negatif mengenai jurusannya cenderung mengalami perasaan negatif seperti adanya konflik psikologis, akademik dan relasional. Konflik yang dialami dapat menyebabkan stres dan memengaruhi kondisi kesehatan mental mahasiswa bahkan hingga memunculkan perilaku negatif seperti tidak mengikuti perkuliahan dengan baik, tidak maksimal saat mengerjakan tugas perkuliahan dan lain-lain. Hal ini juga berlaku sebaliknya, apabila mahasiswa memiliki pemikiran atau persepsi positif terhadap jurusannya, perasaan dan perilaku yang dihasilkan pun akan positif juga.

Sikap merupakan wujud dari evaluasi yang mana nantinya individu tersebut akan menerima atau menolak sesuatu atau situasi tertentu. Individu dapat menerima rangsangan yang diberikan maka akan memunculkan sikap yang positif karena memberikan pengalaman yang menyenangkan. Sedangkan apabila rangsangan ditolak maka akan menimbulkan sikap negatif karena memberikan pengalangan tidak menyenangkan. Pernyataan tersebut didasarkan oleh pendapat Azwar (2002) yang menyatakan bahwa penentuan sikap seseorang merupakan afek positif dan negatif yang dikaitkan dengan suatu objek psikologis sehingga dapat dikatakan sikap berhubungan dengan perasaan seseorang terhadap objek yang tidak terbatas pada tindakan. Karena perasaan dapat berwujud positif dan negatif, sehingga sikap juga dapat dikatakan bersifat dinamis karena dapat berubah-ubah atau dipengaruhi seperti kondisi lingkungan dan situasi.

Sikap yang dapat bersifat negatif maupun positif ini juga dapat dipengaruhi oleh pandangan negatif dari orang lain. Pada konteks mahasiswa yang merasa salah jurusan, pandangan negatif masyarakat terhadap jurusan yang mereka pilih juga dapat mempengaruhi sikap mengenai pilihan jurusan kuliah dan semakin memperburuk perasaan cemas terhadap masa depan tersebut(Kompas, 2015). Memiliki kendali dalam memprediksi dan memikirkan masa depan sangat penting bagi mahasiswa, mengingat semakin banyaknya jumlah pengangguran lulusan sarjana dan mismatch pekerjaan yang dapat berdampak pada kinerja dan kompetensi diri mahasiswa dalam pencapaian akademik dan motivasi yang baik saat di universitas (Hammad, 2016). Hammad juga menjelaskan bahwa mahasiswa di beberapa jurusan mengalami kecemasan sebagai hasil dari hilangnya kepercayaan pada masa depan yang mereka peroleh karena mengetahui sesama alumni yang memiliki peluang kerja terbatas sehingga harus bekerja di bidang yang berbeda atau memilih untuk tidak bekerja.

Kecemasan berkaitan dengan perasaan yang tidak pasti dan tidak berdaya. Kecemasan sendiri merupakan respon emosi terhadap sesuatu yang diperlukan oleh individu sebagai pertahanan hidup terhadap stimuli stres yang dirasakan oleh individu (Stuart, 2007). Kecemasan yang dialami oleh individu dapat diekspresikan melalui sikap atau tindakan, individu melakukan hal ini sebagai upaya melawan kecemasan yang sedang dihadapi. Intensitas perilaku akan meningkat jika semakin banyak munculnya stimulus kecemasan yang dihadapi oleh individu (Stuart, 2007).

Perasaan cemas yang dialami mahasiswa sangat lazim karena mereka mulai memiliki pandangan yang menghubungkan antara kehidupan nyata mereka dengan masa depan penentuan karir yang belum pasti. Terdapat hampir 50\% mahasiswa mengalami kebingungan dalam pengambilan keputusan untuk karir yang akan dijalani karena banyaknya pilihan pekerjaan, pendidikan, dan kebutuhan yang diperlukan di masa depan (Saparingga, 2012). Masa depan yang tidak menentu ini menyebabkan banyak mahasiswa yang merasa cemas akan masa depan, seperti beberapa kasus kecemasan yang relatif lebih umum muncul pada usia dua puluhan atau masa perkuliahan (Hammad, 2016) . Pada usia ini merupakan awal untuk membuat keputusan dalam memilih jenis pekerjaan dan membangun sebuah keluarga. Meskipun usia 18 tahun pun individu sudah dapat melakukan tugas perkembangan dalam mencari pekerjaan (Monks et al., 2001).

Masa depan yang ambigu dan tidak jelas dapat mengarah pada perasaan ketidakberdayaan dan kegelisahan terutama ketika individu merasa bingung dan tidak dapat mengendalikan masa depannya, sehingga membuat individu tersebut tidak dapat merencanakan masa depan yang kemudian mengarah untuk merasakan kecemasan masa depan yang berkelanjutan Hammad (2016). Ceyhan (2010) menjelaskan bahwa salah satu yang menyebabkan 
mahasiswa mengalami stres adalah kecemasan akan masa depan. Kecemasan tersebut dapat berkaitan dengan rencana untuk berkarir maupun melanjutkan studi ke jenjang yang lebih tinggi. Baumgartner \& Fratantoni (2008) mengungkapkan bahwa terkadang orang-orang takut bahwa sebuah peristiwa yang tidak diinginkan dapat terjadi di masa depan, atau berharap bahwa hal itu tidak terjadi dan mereka membayangkan perilaku yang dapat mereka lakukan untuk menghindari bahaya yang akan datang dan memvisualisasikan kelegaan atau perasaan senang ketika hasil yang negatif tidak terwujud.

Berdasarkan latar belakang yang sudah dipaparkan, penulis tertarik untuk meneliti dengan tema hubungan kecemasan masa depan dengan sikap mahasiswa terhadap jurusan akademik. Penelitian ini bertujuan untuk mengetahui hubungan antara kecemasan masa depan dan sikap terhadap jurusan pada mahasiswa. Manfaat penelitian ini terutama kepada mahasiswa yang diharapkan dapat menyikapi dengan perilaku dan pemikiran yang positif untuk menghadapi kecemasan masa depan. Dengan begitu, mahasiswa dapat meminimalisir tingkat kecemasan mereka dan mengoptimalkan kemampuan yang dimiliki. Selain mahasiswa, manfaat penelitian ini juga diberikan kepada tenaga pendidik untuk lebih memberikan dukungan moral seperti motivasi kepada mahasiswa dan memberikan sosialisasi lebih seputar lapangan pekerjaan seperti menjelaskan apa yang dapat diambil setelah mereka lulus nanti. Adapun perbedaan penelitian yang akan dilakukan dengan penelitian sebelumnya terdapat pada perbedaan subjek penelitian, dimana pada penelitian ini peneliti menggunakan mahasiswa di Indonesia khususnya sebagai subjek penelitian.

\section{Metode}

Penelitian ini merupakan penelitian kuantitatif non eksperimen dengan pendekatan korelasional. Dimana penelitian ini bertujuan untuk mengetahui hubungan antara dua variabel. Dengan menggunakan skala sebagai bentuk kuantitatifnya. Skala tersebut akan disebarkan kepada subjek yang sesuai dengan kriteria yang ada. Menurut Azwar (2010), penelitian korelasional mempunyai tujuan untuk mengetahui sejauh mana variasi pada suatu variabel mempunyai kaitan dengan variasi pada variabel lain dengan koefisien korelasi. Sesuai dengan judul penelitian ini, peneliti ingin menguji hubungan antara variabel kecemasan masa depan dan variabel sikap pemilihan jurusan pada mahasiswa.

\section{Subjek Penelitian}

Pengambilan sampel dalam penelitian ini menggunakan teknik purposive sampling, yaitu pengambilan sampel dengan menggunakan kriteria tertentu Sugiyono (2008). Kriteria sampel yang telah ditentutan antara lain: (1) Mahasiswa aktif di Jawa Timur, (2) berjenis kelamin laki-laki dan perempuan, dan (3) berusia minimal 18. Subjek dalam penelitian ini adalah mahasiswa/i di Universitas yang terletak di Jawa Timur, terdapat 150 partisipan dalam penelitian ini dengan deskripsi subjek sebagaimana Tabel 1.

Tabel 1 menjelaskan subjek dalam tiga kategori, yaitu jenis kelamin, jurusan dan usia. Berdasarkan jenis kelamin, mayoritas dalam penelitian ini adalah perempuan dengan prosentase sebesar $70 \%$ dan jurusan yang mendominasi yaitu
Tabel 1. Deskripsi Subjek Penelitian

\begin{tabular}{lll}
\hline Kategori & Frekuensi & Persentase \\
\hline $\begin{array}{l}\text { Jenis Kelamin } \\
\text { Laki-laki }\end{array}$ & 36 & $24 \%$ \\
$\quad$ Perempuan & 114 & $76 \%$ \\
$\quad$ Jurusan & & \\
$\quad$ Saintek & 73 & $49 \%$ \\
$\quad$ Sosial-Humaniora & 77 & $51 \%$ \\
Usia & & \\
$18-21$ & 67 & $43 \%$ \\
$22-24$ & 83 & $57 \%$ \\
\hline
\end{tabular}

Saintek dengan prosentase 58\%. Apabila dilihat dari usia, mayoritas partisipan berusia 22 tahun sebanyak $35 \%$.

\section{Variabel dan Instrumen Penelitian.}

Terdapat dua variabel penelitian yang akan diuji yaitu variabel bebas (X) adalah kecemasan masa depan dan variabel terikat (Y) adalah sikap terhadap jurusan akademik. Variabel bebas merupakan variabel yang mempengaruhi variabel terikat dan variabel terikat merupakan variabel yang terikat atau tergantung pada variabel bebas menurut Creswell (2010).

Kecemasan masa depan adalah kondisi takut dan khawatir akan sesuatu yang tidak diharapkan kedepannya yang mengakibatkan mahasiswa berpikir, berperilaku dan menunjukkan emosi secara negatif serta selalu terpaku pada kejadian saat ini dan mengambil tindakan yang aman untuk mengatasi kecemasannya. Instrumen penelitian variabel ini menggunakan Future Anxiety Scale oleh Hammad (2016). Alat ukur dalam penelitian ini menggunakan skala likert yang disusun 45 item dengan 27 item yang mendukung konsep (favorable) dan 18 item yang tidak mendukung konsep (unfavorable). Skala ini mengukur empat dimensi yaitu a) pemikiran negatif mengenai masa depan, b) kecemasan karir, c) manifestasi dari psikosomatik akibat cemas, dan d) cemas mengenai tekanan hidup.Berdasarkan uji coba penelitian di dapatkan Cronbach's Alpha 0,937.

Sikap terhadap jurusan adalah bentuk wujud dari representasi atas respon yang diberikan oleh stimulus negatif maupun positif kepada mahasiswa terkait pemilihan jurusan. Instrumen yang digunakan dalam penelitian ini yaitu Attitude Toward Academic Specialization Scale oleh Hammad (2016). Alat ukur ini menggunakan skala Likert yang memiliki total 39 item yang terdiri dari 26 item favorable dan 13 item unfavorable. Skala ini mengukur 3 dimensi yaitu a) sikap individu terhadap jurusan akademik, b) sikap sosial terhadap jurusan akademik, c) sikap profesional masa depan terhadap spesialisasi akademik. Berdasarkan uji coba penelitian di dapatkan Cronbach's Alpha 0,964.

Pada kedua variabel diatas setiap item pada kelompok pernyataan tersebut mempunyai lima pilihan jawaban yaitu: Sangat Sesuai (SS), Sesuai (S), Ragu-ragu (R), Tidak Sesuai (TS), dan Sangat Tidak Sesuai (STS). Secara jelas dirincikan sebagai berikut: sangat sesuai pada favorable diberikan nilai 5 dan unfavorable nilai 1, sesuai pada favorable diberikan nilai 4 dan unfavorable nilai 2, normal akan memiliki skor 3 pada pernyataan favorable dan unfavorable, tidak sesuai pada favorable diberikan nilai 2 dan unfavorable nilai 3, 
dan sangat tidak setuju pada favorable diberikan nilai 1 dan unfavorable nilai 4. Sehingga rentang skor pada skala Attitudes Toward Academic Specialization yaitu antara 39 hingga 195 yang mana semakin tinggi skor yang didapat menunjukkan bahwa sikap siswa terhadap jurusan sangat positif. Sedangkan rentang skor skala Future Anxiety yaitu antara 45 hingga 225 yang mana semakin tinggi skor yang didapat menunjukkan bahwa semakin tinggi tingkat kecemasan masa depan.

\section{Prosedur dan Analisis Data}

Dalam penelitian ini jenis data yang digunakan merupakan data interval. Data interval merupakan data yang diperoleh dari hasil pengukuran skala interval. Penelitian yang akan dilakukan memiliki tiga prosedur utama sebagai berikut:

Persiapan, tahap persiapan dimulai dari peneliti melakukan pendalaman materi melalui kajian teoritik serta mencari fenomena-fenomena terkait dengan tema penelitian.

Pelaksanaan, pada tahap pelaksanaan peneliti meminta izin untuk melakukan penelitian (pengambilan data). Peneliti menggunakan uji coba atau try out dengan mahasiswa dengan karakteristik laki-laki dan / atau perempuan yang berusia minimal 18 tahun dan maksimal 23 tahun. Selanjutnya peneliti melakukan analisa data menggunakan uji validitas aiken dengan bantuan software Microsoft Excel dan software Statistical Package For Social Science (SPSS) 25 untuk mendapatkan item valid dan reliabel. Kemudian menyebarkan skala pada subjek penelitian yang memenuhi persyaratan sesuai dengan karakteristik sampel. Alat ukur disebarkan kepada subjek dengan menggunakan google form.

Terakhir, tahap analisis yaitu menganalisa hasil yang didapatkan dari penyebaran skala kepada mahasiswa yang sesuai dengan kriteria yang sudah ditentukan. Proses analisa data menggunakan program SPSS Windows versi 25 dengan analisa korelasi product moment (Usman \& Akbar, 2000). Teknik ini digunakan untuk mengetahui hubungan variabel kecemasan masa depan terhadap sikap mahasiswa berdasarkan jurusan akademik.

\section{Hasil}

Berdasarkan hasil uji normalitas melalui uji KolmogorovSmirnov didapatkan jika Kecemasan Masa Depan memiliki nilai Sig. $=0.200$, pada uji shapiro-wilk didapatakan nilai Sig. $=0.391$. Sedangkan hasil uji normalitas Sikap Mahasiswa Terhadap Jurusan Akademik memiliki nilai Sig. $=0.051$ pada uji Kolmogorov-Smirnov dan uji ShapiroWilk dengan nilai Sig. sebesar 0.053. Hasil perhitungan uji normalitas melalui uji Kolmogorov-Smirnov dan uji ShapiroWilk, kedua data variabel tersebut berdistribusi normal karena memiliki nilai p lebih dari 0,05. Hasil uji linieritas didapatkan hasil 0,632 hal ini menunjukan bahwa kedua variabel linier.

Tabel 2 menjelaskan adanya hubungan positif yang signifikan antara kecemasan masa depan dan sikap terhadap jurusan akademik $(\mathrm{r}=0,325, \mathrm{p}<0.001)$. Selain itu, kecemasan masa depan berkonstribusi secara efektif sebesar 10,6\% terhadap sikap terhadap jurusan akademik. Variabel kecemasan masa depan pada kelompok jurusan akademik saintek $(\mathrm{M}=55,95)$, menunjukkan nilai ratarata yang lebih rendah dibandingkan dengan kelompok jurusan akademik soshum $(M=59,84)$. Sedangkan untuk variable sikap terhadap jurusan akademik pada kelompok jurusan akademik saintek ( $M=52,27)$ memiliki nilai ratarata yang sama dengan kelompok jurusan akademik soshum $(M=52,27)$. Tetapi tidak ada perbedaan signifikan pada tingkat kecemasan masa depan antara mahasiswa jurusan saintek dan soshum, begitu juga pada sikap terhadap jurusan juga tidak ada perbedaan signifikan antara mahasiswa jurusan saintek dan soshum.

\section{Diskusi}

Berdasarkan dari hasil penelitian yang dilakukan diperoleh hasil adanya hubungan positif antara kecemasan masa depan dengan sikap terhadap jurusan akademik. Hubungan positif diartikan bahwa semakin tinggi tingkat kecemasan masa depan maka semakin positif sikap terhadap jurusan akademik. Hasil penelitian ini tidak sesuai dengan hipotesa yang diuji dalam penelitian ini. Hal ini dapat disebabkan karena adanya beberapa hal seperti pembiasan dalam subyek yang mana menurut Hammad (2016) subyek yang mudah mengalami kecemasan berada di usia dua puluhan sedangkan peneliti mengambil sampel dengan menggunakan subyek berusia 18 tahun karena mengacu pada konsep tugas perkembangan menurut Menurut Havighurst (Monks et al., 2001) yang mana individu di usia ini sudah memiliki pandangan karir untuk kedepannya. Selain itu hal lain yang menyebabkan hasil penelitian tidak terbukti sesuai hipotesa peneliti karna adanya perubahan kebutuhan tenaga dan lapangan kerja yang disebabkan oleh pandemi COVID-19. Keadaan pandemi seperti ini telah menimbulkan banyak pelamar kerja terutama para fresh graduated yang berujung menjadi semakin cemas karena merasa tugas perkembangannya yang bertujuan untuk melanjutkan ke jenjang karir tidak tercapai. Karena beberapa perusahaan hanya menerima lulusan dari beberapa jurusan dan berdasarkan pengalaman pekerjaan yang dimiliki.

Selaras dengan penelitian Khairunnisak (2019) salah satu faktor yang mempengaruhi kecemasan menghadapi dunia kerja adalah pikiran yang tidak rasional yang meliputi kegagalan katastropik yakni adanya asumsi dari dalam diri seseorang bahwa akan terjadi sesuatu yang buruk pada dirinya. Asumsi tersebut dapat muncul dari pemikiran kegagalan dalam berkarir. Berdasakan penelitian perasaan cemas akan masa depan yang dialami mahasiswa menghasilkan sikap yang positif. Apabila sikap yang ditunjukkan sikap yang positif terdapat kemungkinan bahwa adanya pengaruh positif dari lingkungan sehingga mahasiswa yang merasa cemas mengenai masa depan memberikan respon positif seperti bersikap positif terhadap jurusan akademiknya. Sikap sendiri menurut Bhaskar \& Soundiraraj (2013) terbentuk dari beberapa sumber seperti keluarga, media dan lingkungan sekolah. Mahasiswa menunjukkan sikap yang positif karena merasa memiliki dukungan yang positif dari alumni yang memiliki jurusan akademik yang sama. Seperti penelitian Muhson et al. (2012) yang menjelaskan bahwa adanya keuntungan dalam membangun relasi dengan alumni sejawat guna mendapatkan informasi tentang kebutuhan dan tuntutan pasar dunia kerja khususnya yang terkait dengan kompetensi yang 
Tabel 2. Nilai Rata-Rata antara Variabel berdasarkan Jurusan Akademik

\begin{tabular}{|c|c|c|c|c|}
\hline \multirow[b]{2}{*}{ Variabel } & \multicolumn{2}{|c|}{ Sains-Teknologi } & \multicolumn{2}{|c|}{ Sosial-Humaniora } \\
\hline & Rata-rata & SD & Rata-rata & SD \\
\hline Kecemasan masa depan & 55,95 & 7,855 & 59,84 & 9,888 \\
\hline Sikap terhadap jurusan & 52,27 & 10,979 & 52,27 & 10,979 \\
\hline
\end{tabular}

Catatan: Hasil uji korelasi dan regresi diperoleh $r=0,325 ; R^{2}=0,106, p=0,000$

diharapkan. Selain itu penyebab mahasiswa menujukkan sikap yang positif terhadap jurusannya karena merasa percaya diri akan jurusan akademiknya. Santrock dalam Puspitasari \& Wiryosutomo (2020) menyebutkan jika percaya diri merupakan perasaan yakin dari diri sendiri bahwa dirinya dapat meraih sesuatu yang diinginkan. Mahasiswa yakin dengan dirinya bahwa jurusan akademiknya akan membawa kemudahan di masa depan.

Terdapat kontribusi efektif sebesar 10,6\% antara kecemasan masa depan dengan sikap terhadap jurusan akademik. Hasil dari kecemasan masa depan tersebut merupakan dampak dari stigmatisasi masyarakat yang menggolongkan beberapa jurusan akademik menjadi jurusan yang baik dan jurusan buruk. Tuntutan keluarga terhadap pilihan jurusan tertentu sehingga membuat anak merasa bersalah apabila memilih jurusan yang tidak sesuai dengan tuntutan keluarga sehingga berujung merasa cemas akan masa depan.

Pada variabel kecemasan masa depan menunjukkan bahwa jurusan akademik sosial-humaniora memiliki tingkat kecemasan yang lebih tinggi dibandingkan mahasiswa jurusan sains-teknologi. Tetapi tidak ada perbedaan signifikan pada tingkat kecemasan masa depan antara mahasiswa jurusan sains-teknologi dan sosial-humaniora, begitu juga pada sikap terhadap jurusan juga tidak ada perbedaan signifikan antara mahasiswa jurusan sains-teknologi dengan sosialhumaniora. Kemungkinan perbedaan terjadi karena adanya perasaan cemas yang disebabkan karena kurangnya lapangan pekerjaan saat ini. Hasil penelitian Hammad (2016) yang menujukkan bahwa apabila kecemasan yang ditunjukkan tinggi maka ia merasa kurang mendapatkan kesempatan untuk mencapai tujuannya. Hammad (2016) pada mahasiswa Universitas Najran di Arab Saudi dengan mengukur kecemasan masa depan berdasarkan jurusan yang mana terlihat adanya perbedaan yaitu mahasiswa dengan jurusan humanistik bahwa lebih cenderung merasa cemas akan masa depan dibandingkan dengan mahasiswa jurusan saintek. Hal tersebut terjadi karena adanya perbedaan berdasarkan pengetahuan dan pengalaman sebelumnya. Pengalaman tersebut dapat berasal dari orang lain seperti alumni sebelumnya yang menjelaskan tentang kesulitan mengenai ketersediaan lowongan pekerjaan yang sesuai dengan jurusan mereka. Dijelaskan juga bahwa lowongan pekerjaan yang tersedia untuk lulusan jurusan humanistik lebih terbatas karena meningkatnya jumlah pengangguran yang terjadi dalam beberapa periode

Sedangkan pada variabel sikap terhadap jurusan akademik apabila ditinjau berdasarkan jurusan akademik, jurusan sosial-humaniora dan sains-teknologi tidak memiliki perbedaan dalam menyikapi jurusan akademik. Hasil tersebut tidak selaras dengan hasil penelitian oleh Hammad (2016) yang mana jurusan akademik saintek memiliki sikap positif terhadap jurusan dibandingkan dengan jurusan akademik sosial-humaniora karena mereka lebih yakin dengan kesempatan bekerja yang diberikan kepada lulusan jurusan saintek.

\section{Kesimpulan}

Kesimpulan dari hasil penelitian yang dilakukan terdapat hubungan positif antara kecemasan masa depan dengan sikap mahasiswa terhadap jurusan akademik. Hubungan positif dapat diartikan bahwa semakin tinggi kecemasan masa depan mahasiswa maka sikap terhadap jurusan akademik yang ditunjukkan adalah sikap yang positif.

Implikasi yang mengacu dari hasil penelitian ini untuk mahasiswa yang sedang merasa cemas terhadap masa depan agar dapat menyikapi jurusan akademiknya dengan positif melalui berabgai upaya untuk mengasah kemampuan diri yang sesuai dengan bakat dan minat walaupun jurusan akademik yang ditempuh tidak sesuai dengan keinginan. Sedangkan untuk orangtua dihimbau untuk lebih sering berkomunikasi dengan anaknya memberikan dukungan terhadap segala pilihan yang diberikan anaknya. Terakhir, kepada tenaga pendidik di tingkat universitas untuk memberikan sosialisasi mengenai karir yang sesuai dengan jurusan akademik dan memberikan motivasi agar mahasiswa tidak merasa cemas mimikirkan karir mengenai masa depan.

\section{Referensi}

Awaliyah, G., \& Murdaningsih, D. (2019, 7 Februari). 87 persen mahasiswa mengaku salah pilih jurusan. Diambil dari https://republika.co.id/berita/pmjuhw368/87-persenmahasiswa-mengaku-salah-pilih-jurusan.

Azwar, S. (2002). Sikap manusia. Edisi II. Yogyakarta: Pustaka Belajar.

Azwar, S. (2010). Metode penelitian. Yogyakarta: Pustaka Pelajar.

Baumgartner, M. F., \& Fratantoni, D. M. (2008). Diel periodicity in both sei whale vocalization rates and the vertical migration of their copepod prey observed from ocean gliders. Limnology and Oceanography, 53(5part2), 2197-2209.

Bhaskar, V. \& Soundiraraj. (2013). A Study on Change in Attitude of Students towards English Language Learning. English Language Teaching. 5(6), 111- 116.

Ceyhan, A. A. (2010). Investigation of university students' selfacceptance and learned resourcefulness: a longitudinal study. High Education, 649-661.

Creswell, J. W. (2010). Mapping the developing landscape of mixed methods research. SAGE handbook of mixed methods in social \& behavioral research, 2, 45-68.

Departemen Kesehatan RI. (2014). Stop Stigma dan Diskriminasi Terhadap Orang dengan Gangguan Jiwa (ODGJ). www.depkes.go.id (diakses pada tanggal 24 Desember 2019) 
Hammad, M. A. (2016). Future anxiety and its relationship to students' attitude toward academic specialization. Journal of Education and Practice, 7(15), 54-65

Hermawan, A. (2012). Komunikasi pemasaran. Jakarta: Erlangga

Khairunnisak. (2019) Hubungan antara kematangan karir dengan kecemasan menghadapi dunia kerja pada fresh graduate universitas islam negeri ar-raniry banda aceh. (Skripsi dipublikasikan). Fakultas Psikologi UIN Ar-Raniry Banda Aceh.

Kompas. (2015, Agustus 13). Kampus baru: Jangan biarkan cemas berlarut-larut. Diunduh dari https://muda.kompas.id/baca/2015/08/13/kampus-barujangan-biarkan-cemas-berlarut-larut/

Monks, F.J., Knoers, A.M.P., \& Haditono, S.R. (2001) Psikologi perkembangan. Yogyakarta: Universitas Gajah Mada

Muhson, A., Wahyuni, D., Supriyanto, \& Mulyani, E. (2012). Analisis relevansi lulusan perguruan tinggi dengan dunia kerja. Jurnal Economia, 8(1), 42-52.

Puspitasari, T.A., Wiryosutomo, H.W., (2020). Hubungan antara percaya diri dan regulasi diri dengan kecemasan berbicara di depan umum pada mahasiswa jurusan bimbingan dan konseling angkatan 2018 universitas negeri surabaya. Jurnal BK UNESA, 11(1)
Rajecki, D. W. (1982) Attitudes, themes and advances, Sinauer Associates, Incorporated

Ramadhan, L. A. (2020, 14 Januari). Angka pengangguran di kota malang tertinggi di jatim. Diambil dari https://beritajatim.com/peristiwa/angka-pengangguran-dikota-malang-tertinggi-di-jatim/

Rimawati, A. B. (2010). Model teoretik prasangka sosial . (Disertasi tidak dipublikasikan). Fakultas Psikologi Universitas Gadjah Mada, Yogyakarta.

Saparingga, H. (2012). Efektivitas pelatihan karir dalam meningkatkan eksplorasi karir pada mahasiswa tingkat akhir Universitas Pendidikan Indonesia.

Setiawan, A. (2013). Salah jurusan. Suara mahasiswa. Diambil dari http://agungjk.tumblr.com

Stuart S. (2007). Buku saku keperawatan jiwa edisi 4. Jakarta : EGC.

Sugiyono. (2008). Metode Penelitian Kuantitatif, Kualitatif dan $R \& D$. Bandung: Alfabeta.

Usman, H., Akbar, P.S. (2000). Pengantar Statistika. Jakarta : Bumi Aksara.

Williams, D. (1984). Attitudes Towards Varieties Of Nigerian Spoken English. World English's, 3(1), 6-10. 